\& J. Edu. \& Sci., Vol. (21), No. (4) 2008 \&

\title{
Synthesis of Some Atophan Derivatives
}

\author{
M. A. Al-Iraqi $\quad$ K. H. Al-Naimi A. H. Al- Sabawi \\ Department of Chemistry / College of Science, \\ Mosul University \\ Iraq
}

Received

07 / 05 / 2007
Accepted

13 / 01 / 2008

\section{lll}

يتضمن البهث تحضير وتشخيص عدد من الاسترات (2-4) المشقة من الاتوفان

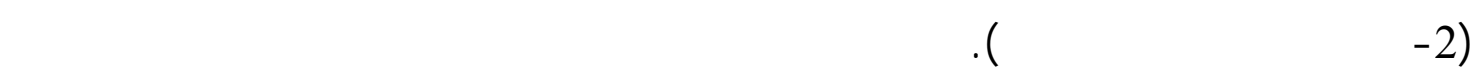
بمعلملتها مع الاثيلين ثنائي أمين، حيث تمر الفاعلات عبن المبر لحد المسارات الآتية. المسار الأول

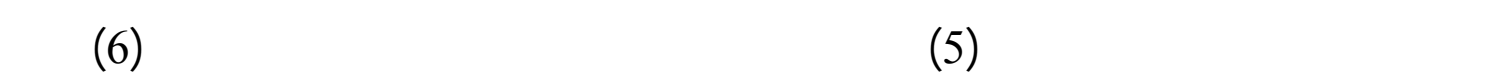

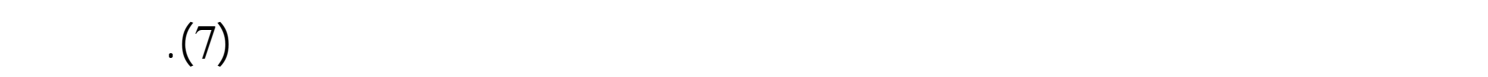

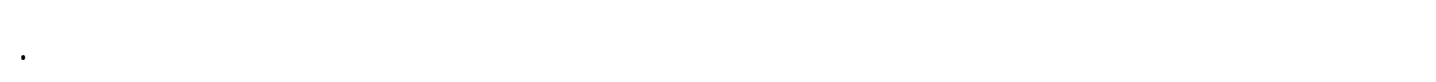

\section{ABSTRACT}

The research was concerned with preparation and characterization of some esters (2-4) derived from atophan (2-phenyl cinchoninic acid). These esters were converted to the corresponding carboxamide by their reaction with ethylene diamine. This reaction may be follow either one of three path ways. The first gives the monocarboxamide (5), whereas the second gives the dicarboxamide (6), while the last one gives a heterocyclic product (7). All the synthesized compounds, have been characterized by physical and infrared and electronic spectral means. 


\section{INTRODUCTION}

The substituted quinoline-4-carboxylic acid present in the core of many physiologically active agents, play interesting therapeutic properties, such compounds have been shown to inhibit several enzymes as well as to modulate the activity of many receptors [1]. Thus they have been described as being useful as an antiheumatic and in the treatment of gout. Moreover they showed efficacy as tumor inhibitor [2], and p-Selectin inhibitor [3], in which the p-Selectin play the predominant role in may diseases. Many substituted quinoline-4-carboxylic acids were used in color photographic developing [2], and as plant growth regulant [4]. Various substituted quinoline carboxamide were described as physiologically active compound with a wide range of potential pharmaceutical applications [5,6]. Pfitzinger reaction of isatin with $\alpha$-methylene carbonyl compounds is widely used for the synthesis of substituted quinoline-4-carboxylic acids [7]. These compounds are useful precursors for the synthesis of corresponding carboxamides, through their reaction with primary and secondary amine in methanol to form the corresponding ammonium salts which on treatment with $\mathrm{POCl}_{3}$ or $\mathrm{SOCl}_{2}$ converted to the corresponding carboxamides. The glycidyl compounds were used to increase the glass transition temperature [8], and were show effective anti tumor cancer in mice [9]. The main goal of the work described in this paper was to synthesize some esters of cinchoninic acid and the convertion of these esters to the carboxamide derivatives. 


\section{EXPERIMENTAL}

\section{General procedures:}

Melting points were measured on an Electrothermal 9300 series digital melting point apparatus and are uncorrected. Infrared spectra were recorded from $\mathrm{KBr}$ discs on Thermo Nicolet FTIR spectrophotometer, only characteristic absorptions are reported. UV spectra were measured for solutions in methanol on Shimadzu (U.V-160) spectrophotometer.

\section{Preparation of 2-(4'-substituted phenyl)cinchoninic acid (1a-c) [10] :}

These compounds were prepared according to Pfitzinger reaction by using a solution ( 0.03 mole) of isatin in $33 \%$ of ethanolic potassium hydroxide and acetophenone or its substituents. Some physical properties of compounds (1a-c) were listed in Table 1.

\section{Preparation of ethyl 2-(4'substituted phenyl)cinchoninate (2b,c) [11] :}

These compounds were prepared according to the published method by using substituted cinchoninic acid $(1 \mathrm{~b}, \mathrm{c})(0.025 \mathrm{~mole})$ in absolute ethanol $(15 \mathrm{ml})$ and concentrated sulfuric acid $(6 \mathrm{ml})$ to give the desired esters. Some of the physical properties were listed in Table 1.

\section{Preparation of allyl 2-(4`-substituted phenyl)cinchoninate (3a-c) [12] :}

A mixture of the appropriate acid (1a-c) (0.01 mole) and potassium hydroxide $(0.56 \mathrm{~g}, 0.01$ mole $)$ and allyl bromide $(1.2 \mathrm{~g}, 0.01$ mole $)$ in acetone $(50 \mathrm{~mL})$ was refluxed for $12 \mathrm{hrs}$. After cooling the reaction mixture, the inorganic salts $(\mathrm{KBr})$ was removed by filtration and the filtrate was concentrated under reduced pressure. The precipitate formed was collected by filtration and recrystallized from ethanol to afford the esters $(3 a-c)$. The physical and spectral data were listed in Table 1.

\section{Preparation of glycidyl 2-(4'substituted phenyl)cinchoninate (4a-c) [13]}

To a mixture of the appropriate acid (1a-c) $(0.04$ mole) and dry pyridine $(0.32 \mathrm{~g}, 0.04$ mole), a solution of epichlorohydrin $(1.15 \mathrm{~g}, 0.0127$ mole) in dry ether $(50 \mathrm{~mL})$ was added. The mixture was refluxed for $5 \mathrm{hrs}$. The resulted pyridinium hydrochloride was filtered off and the filtrate concentrated in vacuo to give the residue, which was stirred with ice-water. The solidified product was filtered off and recrystallized from ethanol-water. The physical and spectral data were listed in Table 1. 


\section{Synthesis of Some Atophan Derivatives.}

Table (1): The physical and spectral data for compounds (2-4)

\begin{tabular}{|c|c|c|c|c|c|c|c|c|c|c|}
\hline \multirow[b]{2}{*}{$\begin{array}{c}\text { Compd. } \\
\text { No. }\end{array}$} & \multirow[b]{2}{*}{$\begin{array}{c}\text { M.p. }{ }^{\circ} \mathrm{C} \\
\text { Observed } \\
\text { Lit. }\end{array}$} & \multirow[b]{2}{*}{$\begin{array}{l}\text { Yield } \\
(\%)\end{array}$} & \multirow[b]{2}{*}{ Colour } & \multicolumn{6}{|c|}{$v \mathrm{~cm}^{-1}(\mathrm{KBr}$ disk $)$} & \multirow[b]{2}{*}{$\begin{array}{c}\text { U.V } \\
\lambda \text { max } \\
(\mathrm{nm}) \\
\text { EtOH }\end{array}$} \\
\hline & & & & $\begin{array}{c}\mathrm{C}= \\
\mathrm{C}\end{array}$ & $\begin{array}{c}\mathbf{C}= \\
\mathbf{N}\end{array}$ & $\begin{array}{c}C= \\
\text { O } \\
\text { ester }\end{array}$ & $\begin{array}{l}\mathrm{C}-\mathrm{O} \\
-\mathrm{C} \\
\text { ester }\end{array}$ & $\begin{array}{c}\mathrm{C}- \\
\mathbf{H} \\
\text { pyrid } \\
\text { ine }\end{array}$ & $\begin{array}{c}C- \\
0 \\
\text { epox } \\
\text { id } \\
\end{array}$ & \\
\hline $1 \mathrm{a}$ & $\begin{array}{c}206-208 \\
(208-210)[14]\end{array}$ & 94 & $\begin{array}{c}\text { Faint } \\
\text { yellow }\end{array}$ & & & & & & & \\
\hline $1 b$ & $\begin{array}{c}212-214 \\
(212-214)[14]\end{array}$ & 78 & Yellow & & & & & & & \\
\hline $1 \mathrm{c}$ & $\begin{array}{c}242-244 \\
(243-245)[14]\end{array}$ & 96 & Yellow & & & & & & & \\
\hline $2 \mathrm{~b}$ & $\begin{array}{c}54-56 \\
(54-56)[15]\end{array}$ & 84 & Yellow & & & & & & & \\
\hline $2 c$ & $91-93$ & 89 & $\begin{array}{c}\text { Faint } \\
\text { yellow }\end{array}$ & $\begin{array}{c}1508 \\
(\mathrm{~s})\end{array}$ & $\begin{array}{c}1587 \\
(\mathrm{~s})\end{array}$ & $\begin{array}{c}1724 \\
(\mathrm{~s})\end{array}$ & $\begin{array}{l}1275 \\
\text { (s) }\end{array}$ & $\begin{array}{c}3058 \\
(\mathrm{w})\end{array}$ & & $\begin{array}{c}337^{*} \\
248\end{array}$ \\
\hline $3 a$ & $\begin{array}{l}\text { Very viscous } \\
\text { oil }\end{array}$ & 85 & Brown & $\begin{array}{l}1509 \\
(\mathrm{~m})\end{array}$ & $\begin{array}{c}1591 \\
(\mathrm{~s})\end{array}$ & $\begin{array}{l}1725 \\
\text { (vs) }\end{array}$ & $\begin{array}{l}1269 \\
(\mathrm{~s})\end{array}$ & $\begin{array}{c}3064 \\
\text { (w) }\end{array}$ & & $\begin{array}{l}358^{*} \\
242\end{array}$ \\
\hline $3 b$ & $\begin{array}{l}\text { Very viscous } \\
\text { oil }\end{array}$ & 89 & Brown & $\begin{array}{c}1504 \\
(\mathrm{~s})\end{array}$ & $\begin{array}{c}1591 \\
(\mathrm{~s})\end{array}$ & $\begin{array}{c}1724 \\
(s)\end{array}$ & $\begin{array}{l}1233 \\
\text { (b) }\end{array}$ & $\begin{array}{l}3057 \\
\text { (w) }\end{array}$ & & $\begin{array}{l}326^{*} \\
204\end{array}$ \\
\hline $3 \mathrm{c}$ & $57-58$ & 71 & $\begin{array}{c}\text { Yellowish } \\
\text { white }\end{array}$ & $\begin{array}{c}1507 \\
(\mathrm{~s})\end{array}$ & $\begin{array}{c}1589 \\
(\mathrm{~s})\end{array}$ & $\begin{array}{c}1723 \\
(\mathrm{~s})\end{array}$ & $\begin{array}{c}1249 \\
(\mathrm{~m})\end{array}$ & $\begin{array}{c}3061 \\
(\mathrm{w})\end{array}$ & & $\begin{array}{c}338^{*} \\
251 \\
\end{array}$ \\
\hline $4 a$ & $54-56$ & 79 & $\begin{array}{l}\text { Yellowish } \\
\text { white }\end{array}$ & $\begin{array}{c}1507 \\
(\mathrm{~m})\end{array}$ & $\begin{array}{c}1587 \\
(\mathrm{~s})\end{array}$ & $\begin{array}{c}1724 \\
\text { (s) }\end{array}$ & $\begin{array}{l}1286 \\
(\mathrm{~m})\end{array}$ & $\begin{array}{l}3066 \\
(\mathrm{w})\end{array}$ & $\begin{array}{l}1248 \\
\text { (s) }\end{array}$ & $\begin{array}{c}340^{*} \\
238,284\end{array}$ \\
\hline $4 b$ & $105-106$ & 68 & $\begin{array}{l}\text { Deep- } \\
\text { yellow }\end{array}$ & $\begin{array}{c}1503 \\
(\mathrm{~s})\end{array}$ & $\begin{array}{c}1591 \\
(\mathrm{~s})\end{array}$ & $\begin{array}{c}1721 \\
(\mathrm{~s})\end{array}$ & $\begin{array}{c}1280 \\
(\mathrm{~s})\end{array}$ & $\begin{array}{c}3050 \\
(\mathrm{w})\end{array}$ & $\begin{array}{c}1246 \\
(\mathrm{~s})\end{array}$ & $\begin{array}{c}345^{*} \\
268\end{array}$ \\
\hline $4 \mathrm{c}$ & $78-80$ & 67 & $\begin{array}{l}\text { Deep- } \\
\text { yellow }\end{array}$ & $\begin{array}{c}1508 \\
(\mathrm{~s})\end{array}$ & $\begin{array}{c}1590 \\
\text { (s) }\end{array}$ & $\begin{array}{c}1724 \\
\text { (s) }\end{array}$ & $\begin{array}{c}1278 \\
(\mathrm{~s})\end{array}$ & $\begin{array}{c}3060 \\
(\mathrm{~s})\end{array}$ & $\begin{array}{c}1249 \\
\text { (s) }\end{array}$ & $\begin{array}{l}344^{*} \\
252\end{array}$ \\
\hline
\end{tabular}

$*$ related $\lambda \max$

Reaction of ethyl 2-(4`-substituted phenyl)cinchoninate $(2 \mathrm{~b}, \mathrm{c})$ with ethylene diamine [16] :

A mixture of the appropriate ester $(2 \mathrm{~b}, \mathrm{c})(0.05$ mole $)$ and ethylene diamine $(9 \mathrm{~g}, 0.15$ mole $)$ in absolute ethanol $(25 \mathrm{~mL})$ was refluxed for 48 hrs. After hot filtration, the residue was treated with cold water $(10 \mathrm{~mL})$ and the solid material was collected by filtration and recrystallized from ethanolwater. The physical and spectral data were listed in Table 2.

\section{Reaction of allyl 2-(4-substituted phenyl)cinchoninate $(3 \mathrm{~b}, \mathrm{c})$ with ethylene diamine :}

A mixture of the allyl ester ( $3 b$ or $3 c)$ ( 0.0066 mole) and ethylene diamine $(1.2 \mathrm{~g}, 0.02 \mathrm{~mole})$ in absolute ethanol $(15 \mathrm{~mL})$, was refluxed for 12 hrs. A precipitate was formed during the reflux. The hot filtration of the mixture gave a solid product, washed with hot water and dried to afford (6b or $6 \mathrm{c})$. Allowing the filtrate to stand overnight at room temperature, a 
crystalline material was obtained $(5 b, c)$ which was collected by filtration. The resulted filtrate was allowed to evaporate at room temperature, another crystalline material $(7 \mathrm{~b}, \mathrm{c})$ was formed, washed with cold water then dried. The physical and spectral data were listed in Table 2.

\section{Cyclization of 2-(p-tolyl)-N-(2-amino ethyl)cinchoninamide (5b) [17] :}

A mixture of compound (5b) ( $0.61 \mathrm{~g}, 0.002$ mole) in $1 \%$ aqueous sodium hydroxide solution $(10 \mathrm{~mL})$ was refluxed for $3 \mathrm{hrs}$. After hot filtration the filtrate was acidified with diluted hydrochloric acid, a precipitate was formed which was filtered off, washed with cold water, dried and recrystallized from ethanol yield (50\%). The physical and spectral data were listed in Table 2.

Table (2): The physical and spectral data for compounds (5-7)

\begin{tabular}{|c|c|c|c|c|c|c|c|c|c|}
\hline \multirow{2}{*}{$\begin{array}{c}\text { Compd. } \\
\text { No. }\end{array}$} & \multirow{2}{*}{ M.p. ${ }^{\circ} \mathrm{C}$} & \multirow{2}{*}{$\begin{array}{c}\text { Yield } \\
(\%)\end{array}$} & \multirow[b]{2}{*}{ Colour } & \multicolumn{5}{|c|}{$v \mathrm{~cm}^{-1}$ (KBr disk) } & \multirow{2}{*}{$\begin{array}{c}\mathrm{U} . \mathrm{V} \\
\lambda \max (\mathrm{nm}) \\
\mathrm{EtOH}\end{array}$} \\
\hline & & & & $\mathrm{C}=\mathrm{C}$ & $\mathbf{C}=\mathbf{N}$ & $\mathrm{C}=\mathbf{O}$ & $\begin{array}{c}=\mathrm{C}-\mathrm{H} \\
\text { pyridine }\end{array}$ & $\mathbf{N}-\mathbf{H}$ & \\
\hline $5 b$ & $138-140$ & 44 & $\begin{array}{c}\text { Faint } \\
\text { yellow }\end{array}$ & $\begin{array}{c}1544 \\
(\mathrm{~m})\end{array}$ & $\begin{array}{c}1591 \\
(\mathrm{~s})\end{array}$ & $\begin{array}{c}1660 \\
(\mathrm{~s})\end{array}$ & $\begin{array}{c}3067 \\
(\mathrm{w})\end{array}$ & $\begin{array}{c}3303 \\
(\mathrm{~s})\end{array}$ & $329 *, 250$ \\
\hline $5 c$ & $174-176$ & 47 & $\begin{array}{c}\text { Faint } \\
\text { yellow }\end{array}$ & $\begin{array}{c}1544 \\
(\mathrm{~s})\end{array}$ & $\begin{array}{c}1590 \\
(\mathrm{~s})\end{array}$ & $\begin{array}{c}1669 \\
(\mathrm{~s})\end{array}$ & $\begin{array}{c}3053 \\
(\mathrm{w})\end{array}$ & $\begin{array}{c}3272 \\
(\mathrm{~s})\end{array}$ & $324 *, 248$ \\
\hline $6 b$ & $324-325$ & 10 & $\begin{array}{c}\text { Yellowish } \\
\text { white }\end{array}$ & $\begin{array}{c}1542 \\
(\mathrm{~s})\end{array}$ & $\begin{array}{c}1589 \\
(\mathrm{~s})\end{array}$ & $\begin{array}{c}1641 \\
(\mathrm{~s})\end{array}$ & $\begin{array}{c}3043 \\
(\mathrm{w})\end{array}$ & $\begin{array}{c}3270 \\
(\mathrm{~s})\end{array}$ & $329 *, 250$ \\
\hline $6 c$ & $360-362$ & 12 & white & $\begin{array}{l}1546 \\
(\mathrm{~m})\end{array}$ & $\begin{array}{c}1591 \\
\text { (s) }\end{array}$ & $\begin{array}{c}1642 \\
\text { (s) }\end{array}$ & $\begin{array}{c}3060 \\
(\mathrm{w})\end{array}$ & $\begin{array}{c}3323 \\
\text { (s) }\end{array}$ & $375^{*}, 284$ \\
\hline $7 b$ & $238-240$ & 30 & $\begin{array}{c}\text { Faint } \\
\text { yellow }\end{array}$ & $\begin{array}{c}1543 \\
(\mathrm{~s})\end{array}$ & $\begin{array}{c}1590 \\
(\mathrm{~s})\end{array}$ & $\cdots$ & $\begin{array}{c}3050 \\
(\mathrm{w})\end{array}$ & $\begin{array}{c}3300 \\
(\mathrm{~s})\end{array}$ & $335^{*}, 253$ \\
\hline $7 \mathrm{c}$ & $350-352$ & 35 & white & $\begin{array}{c}1548 \\
(\mathrm{~s})\end{array}$ & $\begin{array}{c}1591 \\
(\mathrm{~s})\end{array}$ & $\ldots$ & $\begin{array}{c}3049 \\
(\mathrm{w})\end{array}$ & $\begin{array}{c}3303 \\
(\mathrm{~s})\end{array}$ & $328^{*}, 284$ \\
\hline
\end{tabular}




\section{RESULTS and DISCUSSION}

The preparative routes to the synthesized compounds are showed in Scheme 1. We initiate our study on formation of substituted cinchoninamide by employing substituted cinchoninic acid as starting materials. The substituted cinchoninic acids (1a-c) are synthesized according to the reported method [10] then converted, firstly, into the corresponding esters [ethyl esters $(2 b, c)$, allyl esters $(3 a-c)$ and glycedyl esters $(4 a-c)]$. The ethyl esters were synthesized according to the reported method [11], by acid catalyzed esterification of substituted cinchoninic acid with ethanol. The ester $2 \mathrm{c}$ was collected as faint yellow solid material. The conversion of the acids (1a-c) into the corresponding allyl esters (3a-c) can not performed under the acid catalyzed condition, because this method was proved to be problematic, since the allyl group undergoes addition reaction, thus the allyl esters were synthesized by refluxing the acids with allyl bromide under alkaline condition, such as potassium hydroxide, in acetone for $12 \mathrm{hrs}$. The esters $(3 \mathrm{a}, \mathrm{b})$ were collected as a very viscous oil, while the ester $3 \mathrm{c}$ as yellowishwhite solid material.

The glycidyl esters (4a-c) were synthesized as solid materials according to the Sandler method by converting the acids into their organic salts then allowed to react with eipchlorohydrin in dry ether.

The IR spectra [18] of the synthesized esters (2-4) (Table 1) showed a characteristic peak at $v=1721-1725 \mathrm{~cm}^{-1}$ which related to the ester carbonyl bond stretching. Furthermore, the disappearance of the absorption peak for the $\mathrm{O}-\mathrm{H}$ bond stretching at $3270-3340 \mathrm{~cm}^{-1}$ in the IR spectra of the synthesized compounds and the negative results of the iodide-iodate test for the $-\mathrm{COOH}$ group supported the formation of these esters. The UV spectra of compounds (2-4) showed absorption bands at $\lambda$ max (326-358) which indicate the presence of highly conjugated system [19].

The synthesized esters $(2 \mathrm{~b}, \mathrm{c}$ and $3 \mathrm{~b}, \mathrm{c})$ were allowed to react with ethylenediamine in absolute ethanol at the reflux temperature for $12 \mathrm{hrs}$. The esters $(2 b, c)$ gave the corresponding amides $(5 b, c)$ as a sole product, while each of the esters $(3 b, c)$ gave a mixture of products at the same time. The dimmer N,N`-di cinchoninoylethylene diamine $(6 \mathrm{~b}, \mathrm{c})$ was precipitated firstly through the progression of the reaction. The other products mono $\mathrm{N}$-cinchoninoyl ethylenediamine $(5 \mathrm{~b}, \mathrm{c})$ were separated by allowing the filtrate to stand for overnight, while the products 2-cinchoninyl imidazoline $(7 b, c)$ separated on evaporation of the solvent [Scheme 1]. 
M. A. Al-Iraqi \& K. H. Al-Naimi \& A. H. Al- Sabawi
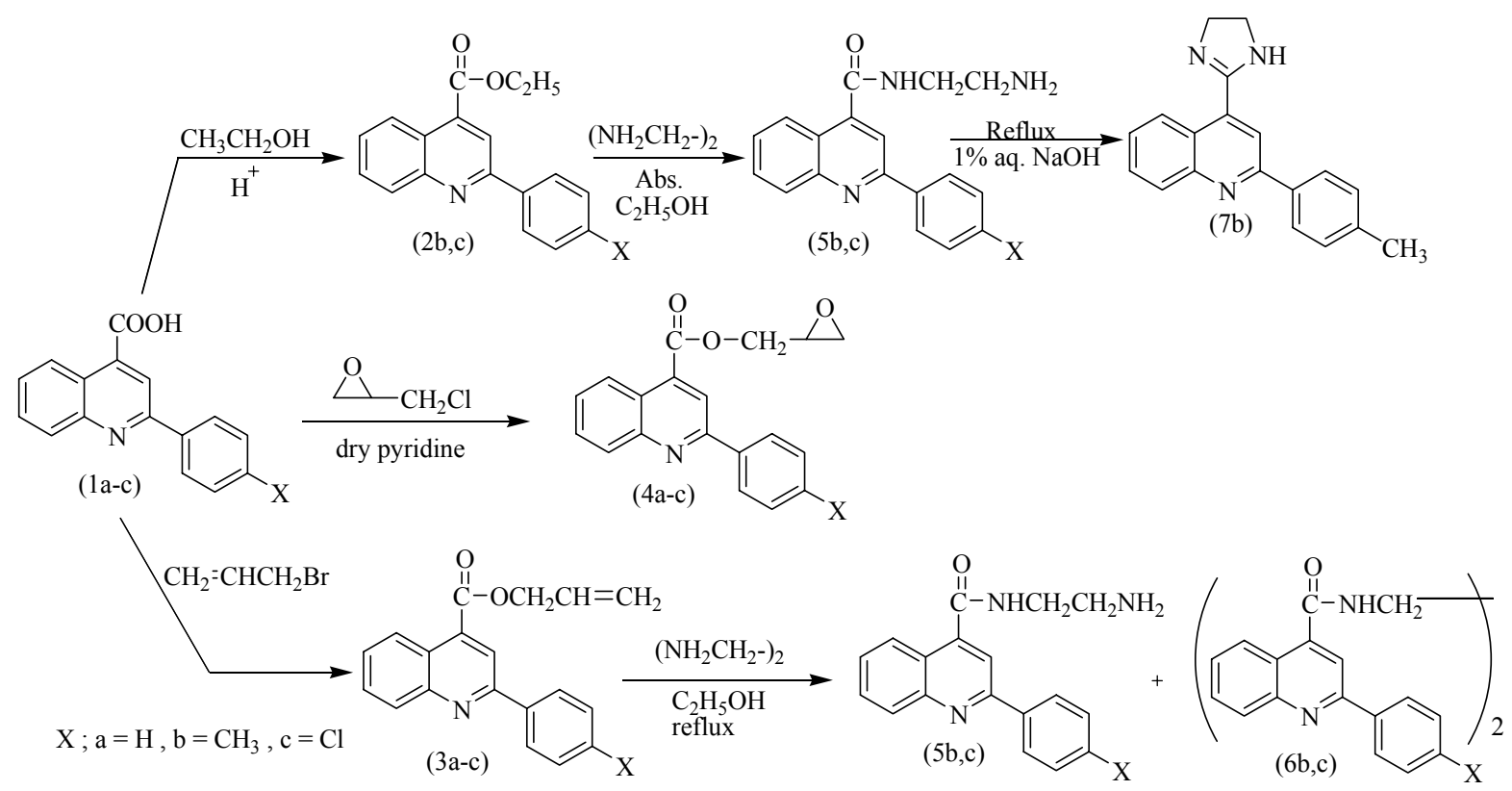

Scheme 1

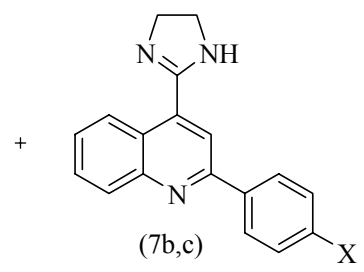

These results can be interpreted through the occurrence of successive reactions. The first one comprises equimolar reaction of the ester with ethylene diamine to form the monocinchoninoyl ethylenediamine $(5 b, c)$ through the following mechanism (Scheme 2).<smiles>[X]c1ccc(-c2cc(C(=O)OCC=C)c3cc[c+](N)ccc3n2)cc1</smiles>

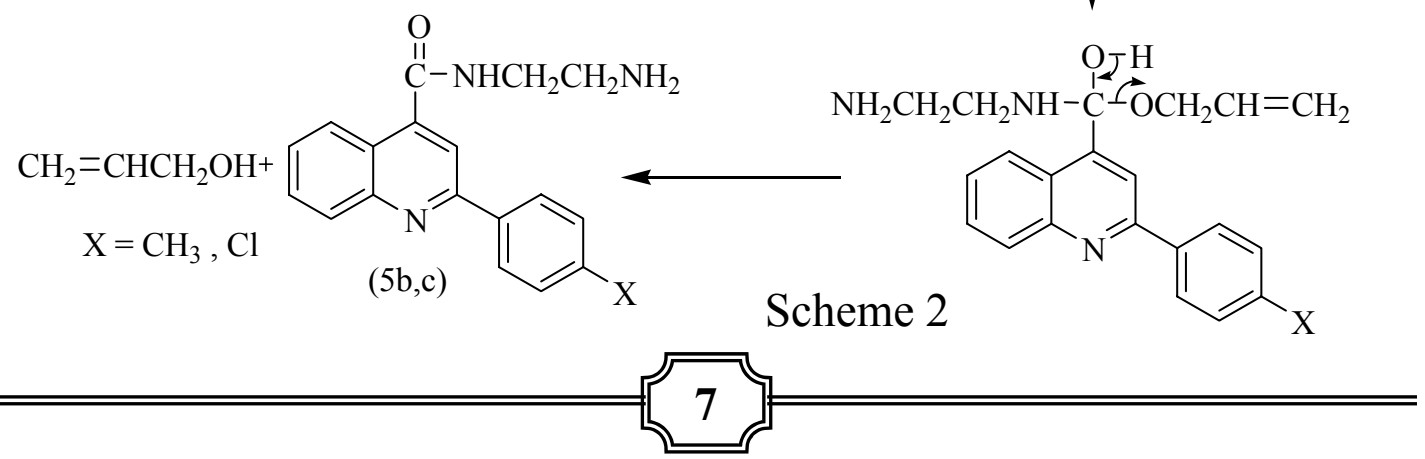


The amides $(5 \mathrm{~b}, \mathrm{c})$ are considered as intermediate products in this reaction and some of them undergo further cinchoninoylation reaction with another molecule of the corresponding ester to form the $\mathrm{N}, \mathrm{N}$ '-dicinchoninoyl ethylenediamine $(6 \mathrm{~b}, \mathrm{c})$ according to the previous mechanism (Scheme 2), which precipitated firstly. The negative Hinsberg test for these compounds emphasized the occurrence of this reaction, i.e. The complete conversion of the amino groups of ethylene diamine to the amido groups.

On the other hand some of the intermediate products $(5 b, c)$ underwent cyclization under basic condition, in which ethylenediamine acts as reactant and base in non aqueous solution to afford the imidazolines ( $7 \mathrm{~b}, \mathrm{c})$, according to the following mechanism [20] (Scheme 3).

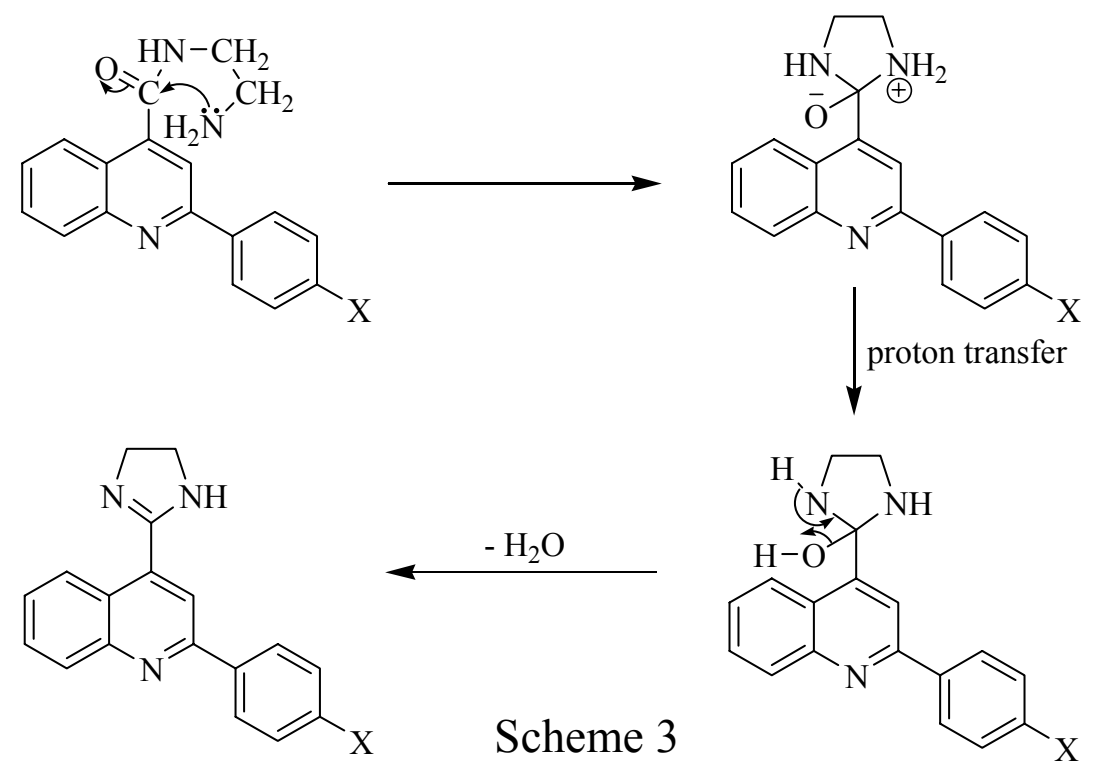

The formation of the imidazoline compounds through this pathway can be confirmed by performing the cyclization of compounds $(5 b)$, that resulted from the reaction of the ethyl ester (2b) with ethylene diamine. The same product was obtained from the two pathways.

The compounds (5-7) were emphasized by IR spectroscopy [18]. The IR spectra of compounds $(5 \mathrm{~b}, \mathrm{c})$ showed absorption peaks at $(1590-1591$ $\left.\mathrm{cm}^{-1}\right),\left(1660-1669 \mathrm{~cm}^{-1}\right)$ and $\left(3303-3272 \mathrm{~cm}^{-1}\right)$ related to $\mathrm{C}=\mathrm{N}, \mathrm{C}=\mathrm{O}$ and $\mathrm{N}-\mathrm{H}$ bond stretching, respectively. The IR spectra of the compounds $(6 \mathrm{~b}, \mathrm{c})$ showed absorption peaks at $\left(1589,1591 \mathrm{~cm}^{-1}\right),\left(1641,1642 \mathrm{~cm}^{-1}\right)$ and $(3270$, $3323 \mathrm{~cm}^{-1}$ ) corresponding to $\mathrm{C}=\mathrm{N}, \mathrm{C}=\mathrm{O}$ and $\mathrm{N}-\mathrm{H}$ bond stretching, respectively, where as the IR spectra of the compounds $(7 \mathrm{~b}, \mathrm{c})$ showed absorption peaks at $\left(1590,1591 \mathrm{~cm}^{-1}\right),\left(3300,3303 \mathrm{~cm}^{-1}\right)$ related respectively to the $\mathrm{C}=\mathrm{N}$ and $\mathrm{N}-\mathrm{H}$ bond stretching of the imidazoline ring. 
The disappearance of the absorption peaks at the range of 1640-1700 $\mathrm{cm}^{-1}$ in the IR spectra of compounds $(7 \mathrm{~b}, \mathrm{c})$ emphasized the absence of carbonyl group and consequently the occurrence of cyclization of the compound $(5 \mathrm{~b}, \mathrm{c})$, i.e. the complete conversion of the amide compounds into the imidazoline compounds .

The UV spectra of compounds (5-7) did not show a significant change in the values of $\lambda$ max, this indicate that their is no change in the conjugated system [19].

\section{REFERENES:}

1. Ivachtchenko A. V., Kobak V. V., Ilyn A. P., Khvat A. V., Kysil V. M., Williams C. T., Kuzovkova J. A. and Kravchenko D. V., J. Comb. Chem., 227, 7, (2005) .

2. Hesson D. P. , U. S. patent, 4, 680 , 299/2000 .

3. Kaila N., Janz K., Huang A., Moretto A., Debernardo S., Bedard P. W., Tam S., Clerin V., Keith J. C., Jr., Tsao H. H., Sushkova N., Shaw G. D., Camphausen R. T., Schaub R. G. and Wang Q., J. Med. Chem., 50, 40-64, (2007).

4. Starke et al, U. S. patent, 4, 009, 020, Feb., 22, (1977).

5. Giardina G. A., Raveglia L. F., Grugni M., Sarau H. M., Farina C., Medhurst A. D., Graziani D., Schmidt D. B., Rigolio R., Luttmann M., Cavagnera J., Foley J. J., Vecchietti V. and Hay D. W., J. Med. Chem., 42, 1053-1065, (1999) .

6. Deady L. W., Desneves J., Kaye A. J., Finlay G. J., Baguley B. C. and Denny W. A., Bio org.. Med. Chem., 8, 977-984, (2000) .

7. Buu-Hoi N. P., Royer R., Xuuong N. D., Jucquignon P., J. Org. Chem., 18, 1209, (1953).

8. Ryan R. W., McGlamery J., Gerald G., Kowolik M. and Keenan M. J., U. S. patent, 6136991 , 10/2000 .

9. Young S. T., Turner T. R. T. and Tarball D. S. , J. Org. Chem., 28, 928, (1963). 
10. Palmer M. H. and Mclntyre P. S., J. Chem. Soc., (B) : 539, (1969) .

11. Sarkis G. Y. and Matti F. S., Iraq J. of Chemistry, 16(1): 52, (1991).

12. Stanley M. S., J. Org. Chem., 57(24), 6427, (1992) .

13. Sandler S. R. and Karo W. , "Organic Functional Group Preparations", Academic Press., New York, San Francisco, London, $12,111,(1968)$.

14. Dupuis R. N. and Lindwall H. G. , J. Am. Chem. Soc., 56, 471, (1934).

15. Al-Naimi K. H. Ph.D. Thesis. University of Mosul (2000).

16. Aspinall S. R., J. Am. Chem. Soc., 63, 852, (1941) .

17. Modi K. F. , Krishnakumar N., Metha H. J. , Padhya A. C. and Somasekhara S., J. Indian. Chem. Soc., 54, 741, (1977) .

18. Parikh V. M. , "Absorption Spectroscopy of Organic Molecules", ترجمة: عبد الحسين شربة، جلم الراوي ومحمد العراقي، 1985، مديرية مطبعة الجلمعة، جلمعة الموصل، (520 -523)، 525، 550.

19. Silverstein R. M., Bassler C. G. and Morvill C. T., "Spectrometric Identification of Organic Compounds", $3^{\text {rd }}$ ed., New York, John Wiley and Sons, Inc., $234,(1974)$.

20. Padhya A. C. and Somasekhara S. J. Indian Chem. Soc., 54, 741, (1977) . 